\title{
Ecological and physiological studies on large intestinal bacteria in relation to production of hydrolytic and reductive enzymes involved in formation of genotoxic metabolites
}

\author{
A. J. McBAIN and G. T. MACFARLANE
}

MRC Dunn Clinical Nutrition Centre, Hills Road, Cambridge CB2 2DH

\begin{abstract}
Several hydrolytic and reductive bacterial enzymes $(\boldsymbol{\beta}$-glucuronidase, GN; $\beta$-glucosidase, GS; arylsulphatase, AS; azoreductase, AR; nitroreductase, NR) involved in production of mutagenic or genotoxic metabolites were measured in human colonic contents. Cellassociated AS and extracellular GS were approximately twice as high in the distal colon compared with the proximal bowel, while AR changed little throughout the gut. Measurements of these enzymes in faeces from seven healthy donors confirmed that the majority were cell-associated, and demonstrated high levels of inter-individual variability. NR decreased four-fold between the proximal and distal colon while extracellular GN was reduced by $50 \%$. Most probable number (MPN) analysis on faeces obtained from six healthy donors showed that counts of intestinal bacteria producing GS and $A R$ were $c .10^{10}$ and $10^{11} / g$, respectively, in all samples tested. Numbers of GN- and AS-forming organisms were between two and three orders of magnitude lower. Interindividual carriage rates of bacterial populations synthesising NR were highly variable. Screening of 20 pure cultures of intestinal bacteria, belonging to six different genera, showed that Bacteroides ovatus, in particular, synthesised large amounts of GS, whereas B. fragilis, B. vulgatus and Bifidobacterium pseudolongum formed the highest cellassociated levels of GN. In general, bifidobacteria and Lactobacillus acidophilus did not produce significant amounts of AR. All five clostridia studied (Clostridium bifermentans, $C$. septicum, $C$. perfringens, $C$. sporogenes and $C$. butyricum) produced $\mathrm{NR}$ and $\mathrm{AR}$, as did the bacteroides ( $B$. fragilis, $B$. ovatus and $B$. vulgatus). Escherichia coli and $C$. perfringens formed large amounts of NR. Levels of AS production were invariably low and few of the organisms screened synthesised this enzyme. In-vitro studies investigating the effect of intestinal transit time on enzyme production, in a three-stage (V1-V3) continuous culture model of the colon operated at system retention times $(R)$ of either 31.1 or $68.4 \mathrm{~h}$, showed that specific activities of GS were up to four-fold higher (V3) at $\mathbf{R}=\mathbf{3 1 . 1} \mathrm{h}$. Bacteriological analysis demonstrated that representative populations of colonic micro-organisms were maintained in the fermentation system, and indicated that changes in GS activity were not related to numbers of the predominant anaerobic or facultative anaerobic species within the model, but were explainable on the basis of substrate-induced modulation of bacterial metabolism.
\end{abstract}

\section{Introduction}

The large intestine harbours the largest and most complex microbial ecosystem associated with the human body, consisting of several hundred different strains of anaerobic bacteria, with numbers exceeding $10^{11} / \mathrm{g}$ of gut contents [1-3]. This microbiota is

Received 12 May 1997; accepted 15 Sept. 1997. Corresponding author: Dr A. J. McBain. involved in the catabolism of a vast range of dietary and endogenously secreted compounds [4, 5]. The products of these biotransformations are often of toxicological significance to the host. For example, colon cancer is known to be greatly influenced by diet, while metabolism of dietary components by intestinal bacteria has been demonstrated to be an important factor in tumour initiation [6-8]. The colonic microflora may be involved in the aetiology of large bowel cancer by chemical modification or activation of a wide 
variety of chemical agents with carcinogenic or cocarcinogenic potential. Exposure of the intestinal microbiota to potential toxicants may occur due to their presence in the diet [9], by biliary excretion of endogenously metabolised substances into the intestine, enzymic activation of procarcinogens by the gut microflora $[10-12]$, or by direct production of mutagenic substances by intestinal micro-organisms [5].

Previous investigations $[10-18]$ have indicated that certain hydrolytic and reductive enzymes produced by intestinal bacteria, such as $\beta$-glucosidase (GS), $\beta$ glucuronidase $(\mathrm{GN})$, azoreductase (AR) and nitroreductase (NR), together with arylsulphatase (AS) [19-25], are capable of metabolising a wide range of compounds in the normal diet, forming toxicologically active products (Table 1). Although the toxicological significance of many of these reductive and hydrolytic bioconversions is at present unclear, the importance of GN and NR in absorption and activation of 1-nitropyrene, a common environmental mutagen, has been demonstrated in vivo [26]. There is also evidence for direct involvement of $\mathrm{GN}$ in carcinogenesis in rats [6].

While previous studies have measured levels of these enzymes in human faeces, and in animal models, there are few data concerning their activities within the colon itself, and little information on the environmental factors that regulate production in human intestinal bacteria.

The objectives of this study were to measure the activities of hydrolytic and reductive enzymes related to genotoxicity in different regions of the large bowel, enumerate and identify the bacterial populations involved, and investigate physiological, environmental and ecological factors that affect their synthesis.

\section{Materials and methods}

\section{Human large intestinal samples}

To compare enzyme activities in different regions of the large bowel, human colonic contents were collected within $4 \mathrm{~h}$ of death from three individuals who had died suddenly, by procedures validated by Cummings et al. [27]. Material was taken from the caecum and ascending bowel (proximal colon), and from the descending bowel and sigmoid-rectum (distal colon). Fresh faeces were also obtained from seven healthy donors (three females, four males, aged 22-63 years), for measurements of hydrolytic and reductive enzymes associated with production of genotoxic substances (Table 1). Immediately after intestinal samples had been obtained, slurries $10 \% \mathrm{w} / \mathrm{v}$ were prepared with anaerobic Tris buffer $(0.1 \mathrm{M}, \mathrm{pH} 7.0)$.

\section{Enzyme assays}

GS, GN and AS activities were determined by methods described by Wise et al. [28]. Samples for analysis of extracellular enzymes were prepared from intestinal contents from which particulate matter had been removed by centrifugation $(20000 \mathrm{~g}, 30 \mathrm{~min})$. Cellassociated enzymes were measured in the pelleted material, which was washed twice and resuspended to the original volume in anaerobic Tris buffer $(0.1 \mathrm{M}, \mathrm{pH}$ 7.0). Substrates were $p$-nitrophenyl $\beta$-D-glucopyranoside, p-nitrophenyl- $\beta$-D-glucuronide, $p$-nitrophenylsulphate $(1 \mathrm{mg} \mathrm{ml})$ respectively, and assays were incubated for up to $120 \mathrm{~min}$ at $37^{\circ} \mathrm{C}$. Because of the lability of $\mathrm{AR}$ and NR, whole culture samples were assayed at 30-, 60- and 120-min intervals. Substrates were prepared in anaerobic potassium phosphate buffer $(0.1 \mathrm{M}, \mathrm{pH} 7.0)$ and comprised amaranth $(0.15 \mathrm{mM})$ and nitrobenzoic acid $(0.06 \mathrm{mM})$, respectively. Rates of enzyme activity were shown to be linear over these incubation times. All assays were carried out in an anaerobic chamber (atmosphere $\mathrm{H}_{2}, 10 \% ; \mathrm{CO}_{2}, 10 \% ; \mathrm{N}_{2}, 80 \%$ ).

Table 1. Hydrolytic and reductive enzymes implicated in the activation or production of mutagenic substances by intestinal bacteria

\begin{tabular}{llll}
\hline Enzyme & Substrate & Reaction & Products/consequences \\
\hline$\beta$-Glucosidase & $\begin{array}{l}\text { Plant glycoside, e.g., methoxyazomethanol } \\
\text { glycoside (from cycad nuts) }\end{array}$ & Hydrolysis & $\begin{array}{l}\text { Toxic aglycone produced (e.g., methoxyazomethanol) } \\
\text { leading to renal tumour formation }\end{array}$ \\
$\beta$-Glucuronidase & $\begin{array}{l}\text { Glucuronic acid conjugates in bile, } \\
\text { e.g., Warfarin glucuronide }\end{array}$ & Hydrolysis & $\begin{array}{l}\text { Increased enterohepatic circulation of toxic parent } \\
\text { compounds, e.g., Warfarin }\end{array}$ \\
Arylsulphatase & Sulphated bile salts, e.g., lithocholate & Hydrolysis & $\begin{array}{l}\text { Increased enterohepatic circulation of lithocholate - } \\
\text { promotion of tumourigenic processes }\end{array}$ \\
Azoreductase & Azo compounds, e.g., Direct Black 38 & Reduction & $\begin{array}{l}\text { Mutagenic aromatic amines produced - toxic (and } \\
\text { pro-mutagenic) compounds, e.g., benzidine and } \\
\text { bladder cancer }\end{array}$ \\
Nitroreductase & Heterocyclic and aromatic nitro compounds, & Reduction & $\begin{array}{l}\text { Mutagenic and carcinogenic heterocyclic amines, } \\
\text { e.g., 6-aminochrysine, a known lung and liver } \\
\text { carcinogen in mice }\end{array}$ \\
\hline
\end{tabular}




\section{Most probable number studies on human faeces}

To quantify bacterial populations forming hydrolytic and reductive enzymes associated with genotoxicity in the large intestine, freshly voided faeces were obtained from six healthy donors. After mixing in a stomacher $(5 \mathrm{~min}), 1-\mathrm{g}$ portions were serially diluted in $9-\mathrm{ml}$ volumes of pre-reduced Wilkins-Chalgren broth. Five replicates of each dilution were prepared. Dilutions between $10^{3}$ and $10^{13}$ were incubated in an anaerobic chamber for 3 days at $37^{\circ} \mathrm{C}$. Samples were then removed for assay of AS, GN, GS, AR and NR. Assays were scored on a $+/-$ basis and most probable numbers were calculated with the 10 -fold dilution, fivereplicate tables of Alexander [29].

\section{Screening of intestinal bacteria for synthesis of} hydrolytic and reductive enzymes involved in genotoxicity

A variety of intestinal bacteria were grown in prereduced peptone yeast extract glucose (PYG) [30] broth in 60-ml serum bottles (Wheaton). Samples from duplicate cultures were taken during exponential growth and the bacteria were removed by centrifugation $(20000 \mathrm{~g}, 30 \mathrm{~min})$. The cell-free culture supernates were retained, as were the bacterial pellets, which were washed twice in anaerobic Tris buffer. Cell-associated and extracellular activities of GS, GN and AS were subsequently determined. AR and NR assays were done with whole cultures, as described previously. The following bacterial cultures were obtained from the National Collection of Food Bacteria, Reading: Clostridium bifermentans 2189; Bacteroides fragilis 2217; Bifidobacterium bifidum 2203; Bif. bifidum 2454; Bif. longum 2716; Bif. longum 2259; Bif. pseudolongum 2244; Bif. angulatum 2236; Bif. angulatum 2237; Bif. breve 2257. C. septicum 286 and C. perfringens 8679 were purchased from the National Collection of Type Cultures, Central Public Health Laboratory, London. $C$. butyricum 19; C. sporogenes $5 ; B$. ovatus $11 ; B$. vulgatus 23; Escherichia coli 20; Enterococcus faecalis 24 and Ent. faecium 26 were isolated from human faeces at the Dunn Clinical Nutrition Centre. Lactobacillus acidophilus 1237 was supplied by $\mathrm{Dr}$ I. R. Rowland, BIBRA Toxicology International.

\section{Factors affecting enzyme synthesis in a three- stage continuous culture model of the large intestine}

A three-stage continuous culture system (Fig. 1) was used to grow mixed populations of intestinal bacteria under environmental conditions (nutrient availability, $\mathrm{pH}$ ) similar to those occurring in the proximal (vessel 1) and distal (vessels 2 and 3) colons. The fermenters were stirred continuously and maintained at $37^{\circ} \mathrm{C}$ with heated water jackets. Operating volumes were $280 \mathrm{ml}$ (V1), $280 \mathrm{ml}$ (V2) and $320 \mathrm{ml}$ (V3); $\mathrm{pH}$ in the fermenters was regulated by New Brunswick modular $\mathrm{pH}$ controllers set at 5.5, 6.2 and 6.8 , respectively. The growth medium consisted of the following $(\mathrm{g} / \mathrm{L})$ in distilled water: pectin, 0.6 ; xylan, 0.6 ; arabinogalactan, 0.6; inulin, 0.6, Lintner's starch, 5.0; guar gum, 0.6; casein, 3.0; peptone water, 3.0 ; yeast extract, 2.5 ; porcine gastric mucin (Sigma Type III), 5.0; tryptone, $3.0 ; \quad \mathrm{K}_{2} \mathrm{HPO}_{4}, \quad 2.0 ; \quad \mathrm{NaHCO}_{3}, \quad 0.2 ; \mathrm{NaCl}, \quad 4.5$; $\mathrm{MgSO}_{4} .7 \mathrm{H}_{2} \mathrm{O}, 0.5 ; \mathrm{CaCl}_{2} .2 \mathrm{H}_{2} \mathrm{O}, 0.45$; cysteine, 0.4; $\mathrm{FeSO}_{4} .7 \mathrm{H}_{2} \mathrm{O}, 0.005$; haemin, 0.01 ; bile salts, 0.05 ; Tween $80,2.0$. The three fermenters were each inoculated twice with $30-\mathrm{ml}$ volumes of a $40 \% \mathrm{w} / \mathrm{v}$ slurry prepared from freshly voided faeces from a healthy donor, with an interval of $48 \mathrm{~h}$ between inoculations. For the first $52 \mathrm{~h}$, anaerobic conditions were maintained by continuous sparging with oxygenfree nitrogen $(2.4 \mathrm{~L} / \mathrm{h})$. Thereafter, the system remained anaerobic without external gassing. After equilibration for a further $25 \mathrm{~h}$, sterile medium was pumped to $\mathrm{Vl}$, which sequentially fed the other two vessels via a series of weirs, to give a total system retention time (R) of either $31.1 \mathrm{~h}$ or $68.4 \mathrm{~h}$. Retention time was calculated as the reciprocal of dilution rate, and total system retention time was taken as the sum of individual retention times for each fermentation vessel. Following establishment of putative steady state conditions (nine culture turnovers), samples of spent culture fluid $(50 \mathrm{ml})$ were removed on at least three separate occasions at a minimum of two system culture turnovers apart. From each sample, $40 \mathrm{ml}$ was prepared as outlined above for determination of enzyme activities involved in synthesis of toxic metabolites. Enumeration of marker bacterial populations was achieved as follows: samples $(1 \mathrm{ml})$ were serially diluted in half-strength, pre-reduced peptone water under anaerobic conditions, and $0.1-\mathrm{ml}$ volumes of selected dilutions were plated, in triplicate on to the following culture media, which had been pre-reduced for at least $12 \mathrm{~h}$ in an anaerobic cabinet: WilkinsChalgren agar (total anaerobes), MRS agar (bifidobacteria and lactobacilli), Beerens agar [31] (bifidobacteria), Rogosa agar (lactobacilli), azide blood agar base (anaerobic cocci and enterococci), MacConkey agar no. 2 (enterobacteria and enterococci), perfringens agar with antibiotic supplements ( $C$. perfringens) and bacteroides mineral salts medium (Bacteroides spp.) [32]. Aerobic populations were enumerated with nutrient agar. Plates were incubated for up to 5 days (aerobically or in an anaerobic cabinet) and the predominant bacteria were identified by morphology, Gram's reaction, API identification tests (bioMerieux) and fermentation product formation [33].

\section{Culture dry weights}

These measurements were made as described by Degnan and Macfarlane [34].

\section{Chemicals}

Unless otherwise stated, all chemicals were obtained from Sigma. Bacteriological culture media were purchased from Unipath. 


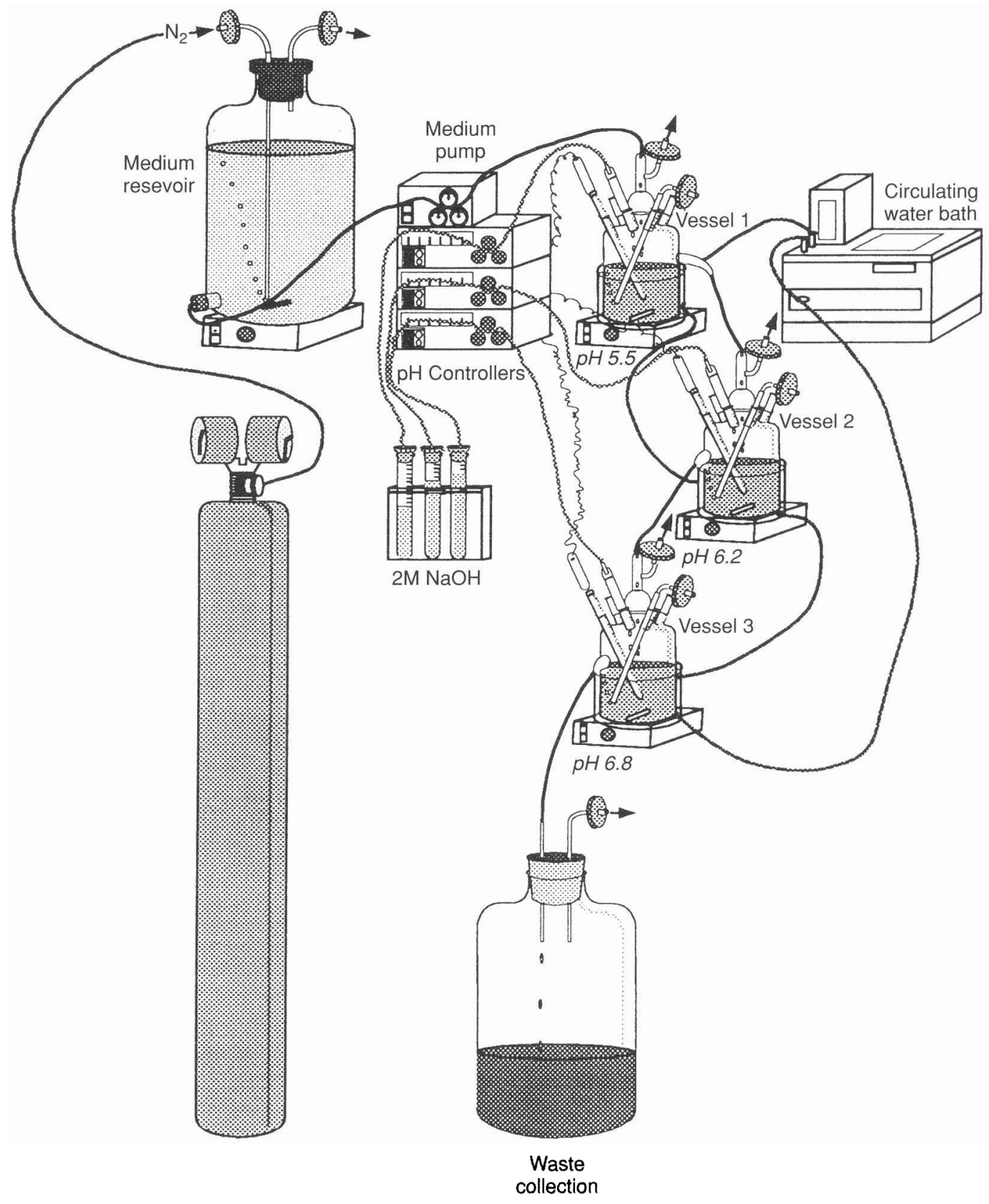

Fig. 1. The three-stage continuous culture model of the large intestine.

\section{Results}

Hydrolytic and reductive enzyme activities in different regions of the large intestine

These enzymes were measured in samples taken from the proximal and distal colons of three persons who had died suddenly (Table 2). Significant GS, GN, NR, $\mathrm{AR}$ and AS activities were detected, although distinct regional variations in activity were observed with some enzymes. For example, cell-bound AS and GS activities were considerably higher in the distal bowel than in the proximal colon; conversely, NR activity in the proximal bowel was approximately twice as high as in the distal large intestine. AR and cell-bound GN levels remained relatively constant throughout the large gut. The majority of GS and GN was cell-associated, but comparatively high levels of extracellular GN and AS activities were present in colonic contents.

\section{Hydrolytic and reductive enzyme activities in faeces}

Data in Table 3 show that faecal activities of all five test enzymes were similar to those measured in intestinal contents. However, the range of activities in different faecal samples was considerable. Thus, GN could not be detected in some faeces, whereas other individuals had very high activities. With respect to GS, GN and AS, their activities were mainly cellbound, with the overall cellular distribution of activities 
Table 2. Comparison of reductive and hydrolytic enzyme activities in proximal and distal regions of the human large bowel

\begin{tabular}{|c|c|c|c|c|c|c|c|c|}
\hline \multirow[b]{2}{*}{ Area of colon } & \multicolumn{2}{|c|}{ GS activity } & \multicolumn{2}{|c|}{ GN activity } & \multicolumn{2}{|c|}{ AS activity } & \multirow{2}{*}{$\frac{\text { NR activity }}{W}$} & \multirow{2}{*}{$\frac{\text { AR activity }}{\mathrm{W}}$} \\
\hline & $\mathrm{E}$ & $\mathrm{C}$ & $\mathrm{E}$ & $\mathrm{C}$ & $\mathrm{E}$ & $\mathrm{C}$ & & \\
\hline Proxim & $24.4(2.16)$ & $117(20.5)$ & $85.1(6.2)$ & $103 \quad(11.8)$ & $13.9(2.3)$ & $11.8(1.8)$ & 3.4 (1.9) & $8.2(9.1)$ \\
\hline Distal & $49.9(0.77)$ & $154(92.3)$ & $36.8(0.9)$ & $92.5(11.6)$ & $11.7(3.1)$ & 26.7 (3.6) & $8.6(0.9)$ & $6.0(3.2)$ \\
\hline
\end{tabular}

Results are mean (SEM) values of three determinations from samples obtained from three individuals. Results are $\mu$ mol substrate reduced or hydrolysed $/ \mathrm{h} / \mathrm{g}$ dry wt intestinal contents.

$\mathrm{GS}, \beta$-glucosidase; GN, $\beta$-glucuronidase; AS, arylsulphatase; NR, nitroreductase; AR, azoreductase; E, extracellular; C, cell-bound; W, whole culture.

Table 3. Activities of hydrolytic and reductive enzymes involved in production of mutagenic substances in human faeces

\begin{tabular}{|c|c|c|c|c|c|c|c|c|}
\hline \multirow[b]{2}{*}{ Measurement } & \multicolumn{2}{|c|}{ GS activity } & \multicolumn{2}{|c|}{ GN activity } & \multicolumn{2}{|c|}{ AS activity } & \multirow{2}{*}{$\frac{\text { NR activity }}{W}$} & \multirow{2}{*}{$\frac{\text { AR activity }}{\mathrm{W}}$} \\
\hline & E & $\mathrm{C}$ & E & $\mathrm{C}$ & E & $\mathrm{C}$ & & \\
\hline Range & $4.5-112$ & $53.9-557$ & $0-39.1$ & $0-388$ & $0-1.2$ & $0-17.2$ & $1.9-5.6$ & $3.8-7.2$ \\
\hline Mean & 34.7 & 307 & 7.7 & 57.6 & 0.1 & 5.6 & 3.7 & 5.5 \\
\hline
\end{tabular}

Measurements were made with material obtained from seven healthy donors. Results are $\mu$ mol substrate metabolised/h/g dry wt faeces. See footnote to Table 2 .

being similar to those of colonic contents. AS levels were low in all the faecal donors, whilst high levels of GS and NR were detected.

\section{Most probable number studies on human faeces}

Fig. 2 shows that all faecal donors harboured substantial populations of bacteria capable of synthesising GS, GN, NR, AR and AS. However, the range of bacterial numbers in different individuals varied for each enzyme: AR and GS were the most ubiquitously produced, with numbers of associated bacteria being at least $10^{11} / \mathrm{g}$ of faeces in all donors. MPN values obtained for bacteria that produced AR were identical

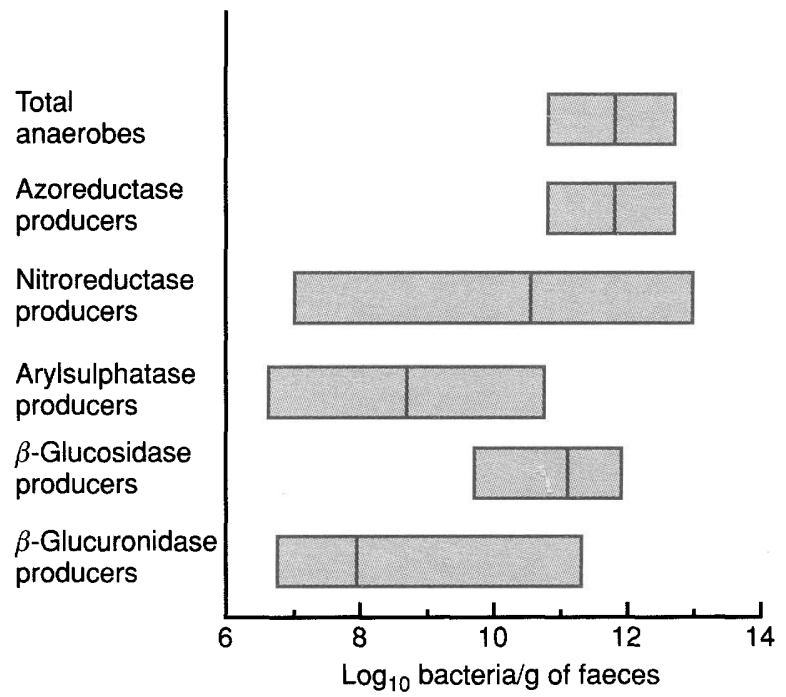

Fig. 2. Enumeration of faecal bacterial populations forming hydrolytic and reductive enzymes associated with the production of genotoxic and mutagenic substances. Results are from most probable number (MPN) measurements with faecal samples from six healthy volunteers. Data show ranges and means (bars). to the total anaerobe counts. Populations of NRproducing organisms varied over six orders of magnitude $\left(\log _{10}\right)$ in the six volunteers studied. Although GN and AS were the least commonly detected enzymes in faeces (Table 3), in all individuals, cell numbers of organisms capable of their synthesis exceeded $10^{6} \mathrm{~g}$ of faeces.

\section{Screening of individual intestinal bacterial} species for synthesis of hydrolytic and reductive enzymes associated with genotoxicity

Twenty intestinal isolates, belonging to six different anaerobic and facultative bacterial genera, were tested for their abilities to produce GN, GS, NR, AR and AS. The activities of these enzymes varied considerably in different gut micro-organisms (Table 4). GS and AR were formed by many different types of bacteria, whereas GN and AS were synthesised by relatively few species. Generally, the highest activities were detected with GS; AS and GN activities were low in comparison. Clostridium spp. and Bacteroides spp. were the major producers of AR and NR. B. ovatus formed high levels of AR and GS. C. perfringens and E. coli synthesised considerable amounts of NR, whereas Bifidobacterium spp. generally formed considerable cell-bound GS. GN and AR production was low in this genus.

Effect of retention time on enzyme formation and intestinal bacterial populations in a three-stage continuous culture model of the colon

Simple measurements of bacterial enzyme activities in colonic contents or faecal material provides little information on the nutritional and environmental factors that affect their synthesis. For this reason, a three-stage continuous culture model of the large 
Table 4. Intestinal bacteria screened for synthesis of hydrolytic and reductive enzymes involved in genotoxicity

\begin{tabular}{|c|c|c|c|c|c|c|c|c|c|}
\hline \multirow{3}{*}{ 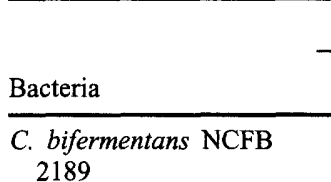 } & \multicolumn{2}{|c|}{ GN activity } & \multicolumn{3}{|c|}{ GS activity } & \multicolumn{2}{|c|}{ AS activity } & \multirow{2}{*}{$\frac{\text { NR activity }}{\text { W }}$} & \multirow{2}{*}{$\frac{\text { AR activity }}{\mathrm{W}}$} \\
\hline & E & $\mathrm{C}$ & $\mathrm{E}$ & C & & $\mathrm{E}$ & $\mathrm{C}$ & & \\
\hline & $0.6(0.0)$ & $\mathrm{T}$ & $\mathrm{T}$ & 3.1 & $(0.2)$ & $\mathrm{T}$ & $\mathrm{T}$ & $4.2(0.0)$ & $0.3(0.1)$ \\
\hline C. septicum NCTC 286 & ND & ND & $0.2 \quad(0.2)$ & ND & & ND & ND & $0.1(0.1)$ & $0.4(0.1)$ \\
\hline C. perfringens NCTC 8679 & ND & $0.3(0.1)$ & $\mathrm{T}$ & 3.9 & $(0.8)$ & $0.8(0.1)$ & ND & $53.8(0.2)$ & $43.7(0.4)$ \\
\hline C. butyricum DCNC 19 & $1.2(0.2)$ & $0.3(0.1)$ & $\mathrm{T}$ & 0.65 & $(0.0)$ & $\mathrm{T}$ & $\mathrm{T}$ & $\mathrm{T}$ & ND \\
\hline C. sporogenes $\mathrm{DCNC} 5$ & ND & ND & $4.4(0.1)$ & $\mathrm{T}$ & & $\mathrm{T}$ & ND & $1.1(0.1)$ & $4.3(0.1)$ \\
\hline B. ovatus DCNC 11 & $0.3(0.1)$ & ND & $110 \quad(6.1)$ & 310 & $(96.0)$ & $.1(0.0)$ & ND & $1.1(0.2)$ & $23.9(1.6)$ \\
\hline B. fragilis NCFB 2217 & $1.1(0.6)$ & $7.2(0.8)$ & $1.3(0.1)$ & 32.6 & $(2.8)$ & $\mathrm{T}$ & $0.8(0.0)$ & $\mathrm{T}$ & $0.3(0.1)$ \\
\hline B. vulgatus DCNC 23 & $\mathrm{~T}$ & $3.1(0.1)$ & $\mathrm{T}$ & 24.2 & $(0.5)$ & $\mathrm{T}$ & $2.6(0.9)$ & $25.9(0.5)$ & $2.5(0.5)$ \\
\hline E. coli DCNC 20 & $1.6(0.6)$ & $1.4(0.1)$ & $0.8(0.2)$ & 0.5 & $(0.2)$ & $0.8(0.1)$ & ND & $4.8(0.0)$ & $0.3(0.1)$ \\
\hline Ent. faecalis DCNC 24 & ND & $0.5(0.1)$ & ND & 2.7 & (1.1) & ND & $\mathrm{T}$ & $10.3(0.4)$ & $28.5(0.7)$ \\
\hline Ent. faecium DCNC 26 & $\mathrm{~T}$ & $\mathrm{~T}$ & ND & 3.7 & $(0.2)$ & $\mathrm{T}$ & $2.8(3.2)$ & ND & $2.0(0.7)$ \\
\hline $\begin{array}{l}\text { L. acidophilus DCNC } \\
1237\end{array}$ & $0.1(0.0)$ & $\mathrm{T}$ & $0.8(0.1)$ & 4.3 & $(0.6)$ & $\mathrm{T}$ & $\mathrm{T}$ & $4.4(0.8)$ & $2.3(0.1)$ \\
\hline Bif. bifidum NCFB 2203 & $1.9(0.1)$ & $0.9(0.4)$ & $0.3(0.0)$ & 6.7 & $(1.0)$ & $0.2(0.0)$ & $0.6(0.4)$ & $4.0(0.2)$ & ND \\
\hline Bif. bifidum NCFB 2454 & $\mathrm{~T}$ & $\mathrm{~T}$ & $\mathrm{~T}$ & 11.6 & $(0.0)$ & ND & $1.3(0.3)$ & $94.0(0.1)$ & ND \\
\hline Bif. longum NCFB 2716 & $0.2(0.1)$ & $0.4(0.0)$ & $\mathrm{T}$ & 15.1 & (0.6) & ND & $\mathrm{T}$ & $6.1(0.9)$ & $1.1(0.2)$ \\
\hline Bif. longum NCFB 2259 & $\mathrm{~T}$ & $1.2(0.3)$ & ND & 1.6 & $(0.2)$ & ND & ND & $9.4(0.6)$ & ND \\
\hline $\begin{array}{l}\text { Bif. pseudolongun NCFB } \\
2244\end{array}$ & $\mathrm{~T}$ & $2.4(0.2)$ & $0.5(0.3)$ & 31.1 & $(0.1)$ & $\mathrm{T}$ & $1.7(0.3)$ & $\mathrm{T}$ & ND \\
\hline $\begin{array}{l}\text { Bif. angulatum NCFB } \\
2236\end{array}$ & $\mathrm{~T}$ & $0.3(0.2)$ & ND & 9.8 & $(0.5)$ & ND & $\mathrm{T}$ & $\mathrm{T}$ & ND \\
\hline $\begin{array}{l}\text { Bif. angulatum NCFB } \\
2237\end{array}$ & $\mathrm{~T}$ & $0.9(0.2)$ & $2.1(0.2)$ & 28.9 & (1.4) & $\mathrm{T}$ & $\mathrm{T}$ & ND & ND \\
\hline Bif. breve NCFB 2257 & ND & $1.6(0.2)$ & $\mathrm{T}$ & 6.9 & $(0.8)$ & ND & $\mathrm{T}$ & $\mathrm{T}$ & ND \\
\hline
\end{tabular}

ND, not detected; $\mathrm{T}$, trace $(<0.10)$. ( ), SD of two separate experiments. Results are $\mu$ mol substrate metabolised/h/g dry wt bacteria.

See footnote to Table 2.

intestine was used to study the effects of nutrient availability and intestinal transit time on enzyme formation in vitro. Expression of hydrolytic and reductive enzymes involved in synthesis of intestinal mutagens varied in different vessels of the fermentation system (Table 5). As was found in intestinal contents, the great majority of GS and GN activity was cellassociated. Extracellular and cell-bound activity of these enzymes increased from V1 to $\mathrm{V} 3$ at $\mathrm{R}=31.1 \mathrm{~h}$, but with the exception of extracellular GS, this did not occur at $\mathrm{R}=68.4 \mathrm{~h}$. Cell-bound GS was four-fold higher in $\mathrm{V} 3$ at $\mathrm{R}=31.1 \mathrm{~h}$ than at $\mathrm{R}=68.4 \mathrm{~h}$. Azoreductase also increased from $\mathrm{V} 1$ to $\mathrm{V} 3$, but activities of this enzyme were higher in all fermentation vessels at $R=68.4 \mathrm{~h}$. Nitroreductase synthesis progressively declined from $\mathrm{V} 1$ to $\mathrm{V} 3$ at $\mathrm{R}=31.1 \mathrm{~h}$. However, the activity of this enzyme increased considerably in all culture vessels when retention time was extended to $68.4 \mathrm{~h}$, being 15 -fold greater in V3 under these growth conditions.

Anaerobic bacteria predominated in all culture vessels, outnumbering facultative micro-organisms by two to three orders of magnitude (Table 6 ). Increasing $R$ to $68.4 \mathrm{~h}$ gave higher recoveries of virtually all bacterial groups, although this effect was most significant with the facultative populations. This was primarily related to increases in enterobacterial and enterococcal cell numbers. The major intestinal anaerobes were detected in the gut model, with Bacteroides spp. (B. fragilis group) being most numerous, although significant populations of lactobacilli and bifidobacteria were also recorded, particularly at $\mathrm{R}=68.4 \mathrm{~h}$.

\section{Discussion}

The large intestine is the second most common site for carcinoma in man [35] and faeces from individuals living in Western societies frequently contain mutagenic substances, as indicated by the Ames test [36, 37]. Hitherto, there has been no general agreement regarding the aetiology of bowel cancer, although factors such as diet, environment and genetics have all been implicated [38]. It has been speculated that tumours occur 100 times more often in the hindgut than in the small intestine [39], indicating that the colonic microbiota plays an important role in carcinogenesis. It has also been suggested that a mechanism whereby intestinal bacteria may be involved in these processes is by the production of carcinogenic metabolites from non-toxic precursor molecules [40], and a variety of hydrolytic and reductive enzymes responsible for carcinogen production are known to be produced by colonic micro-organisms (Table 1).

The proximal large bowel in healthy individuals is inaccessible for routine microbiological investigation. For this reason, most studies on the colonic microbiota have focused on faecal material. However, bacterial populations and their metabolic activities in faeces may not be representative of those in the caecum and ascending colon. Therefore, in this investigation, digestive material was obtained from different regions of the large intestines of persons who had died suddenly, for comparative determinations of cell-bound and extracellular bacterial enzyme activities involved in production of genotoxins. 
Glycosidase measurements (GS, GN) confirmed previous observations that these enzymes were primarily cell-associated in colonic contents [41]. Attempts to characterise $A R$ and NR in this way resulted in substantial losses in activity, even when anaerobic procedures were used. Therefore, their activities were measured in whole cultures. Table 2 shows distinct regional differences in the activities of several enzymes in the large gut. The proximal colon contained significantly higher amounts of total (extracellular and cell-bound) GN and NR, while digestive material in the distal bowel contained considerably higher levels of GS and total AS. Despite these marked differences, the overall physiological significance of these enzyme activities to the host is unclear, as many other factors affect the production and activities of mutagenic substances in the colon, such as availability of precursor substrates and degradation or bioconversion of mutagenic compounds to nontoxic substances by intestinal bacteria, while mutagenic or genotoxic metabolites may be inactivated by non-specific binding to particulate substances in the gut lumen.

The large inter-individual variations in faecal activities of enzymes associated with genotoxicity (Table 3 ) can be explained in terms of carriage rates of specific bacterial populations, community structure of the microbiota, differences in host physiologies, such as hepatic and biliary secretory activities and intestinal transit times, which govern substrate availabilities in different regions of the colon, as well as diet, which affects levels of inducer and repressor substances reaching the large gut.

Studies with rats have demonstrated that diet can have a significant effect on enzyme synthesis in intestinal bacteria [42]. When animals fed a grain-based meal were changed to a predominantly meat diet, they excreted significantly higher levels of faecal NR, AR and GN, while GS activities in faeces were reduced. From these observations, it was suggested that the association of high meat diets and colon cancer in man could be linked to bacterial enzyme expression. Changes in GN in the rats, which was a slow process occurring over many days, was believed to result from alterations in the species composition of the colonic microbiota, rather than modulation of bacterial metabolic profiles, whilst the reduction in GS was associated with down-regulation of enzyme synthesis. Other environmental factors influence bacterial enzyme activities in the large intestine, for example, intracellular GN in $E$. coli and $C$. perfringens has been reported to be increased by bile salts [43], whereas GN and bile acid excretion in human faeces are known to be elevated during consumption of high fat diets $[44,45]$.

Enumeration of faecal micro-organisms forming hydrolytic and reductive enzymes involved in producing 
Table 6. Marker bacterial populations in the three-stage continuous culture model of the large intestine

\begin{tabular}{|c|c|c|c|c|c|c|}
\hline \multirow[b]{2}{*}{ Marker group } & \multicolumn{3}{|c|}{$\mathrm{R}=31.1 \mathrm{~h}$} & \multicolumn{3}{|c|}{$\mathrm{R}=68.4 \mathrm{~h}$} \\
\hline & V1 & $\mathrm{V} 2$ & V3 & V1 & $\mathrm{V} 2$ & $\mathrm{~V} 3$ \\
\hline Total anaerobes & $9.3(0.5)$ & $9.0(0.1)$ & $8.4(0.2)$ & $9.8(0.6)$ & $10.0(0.6)$ & $9.5(0.1)$ \\
\hline Total aerobes & $5.0(0.1)$ & $5.6(0.3)$ & $5.6(0.1)$ & $7.8(0.1)$ & $7.3(0.3)$ & $7.5(0.1)$ \\
\hline Bifidobacteria & $6.4(0.5)$ & $7.0(0.1)$ & $6.4(0.2)$ & $7.6(0.2)$ & $6.2(0.7)$ & $8.4(0.3)$ \\
\hline B. fragilis group & $8.0(0.1)$ & $8.0(0.2)$ & $8.1(0.9)$ & $8.9(0.2)$ & $9.3(0.2)$ & $7.9(0.3)$ \\
\hline C. perfringens & $6.4(0.1)$ & $6.5(0.4)$ & $7.0(1.4)$ & $8.7(0.6)$ & $7.5(0.5)$ & $8.9(1.1)$ \\
\hline Lactobacilli & $7.7(0.7)$ & $7.9(0.2)$ & $7.8(0.3)$ & $8.3(0.5)$ & $8.9(0.7)$ & $8.0(0.2)$ \\
\hline Anaerobic cocci and enterococci & $6.6(0.1)$ & $6.0(0.1)$ & $6.3(0.6)$ & $8.3(0.1)$ & $8.6(0.5)$ & $8.4(0.1)$ \\
\hline Enterobacteria & $4.9(0.2)$ & $4.7(0.5)$ & $4.0(0.1)$ & $7.6(0.2)$ & $6.9(0.6)$ & $7.2(0.1)$ \\
\hline
\end{tabular}

Counts are $\log _{10} \mathrm{cfu} / \mathrm{ml}$; results are means (SD), $\mathrm{n}=3$.

genotoxic substances, by MPN methods, demonstrated that the predominant colonic anaerobes formed AR. Moreover, these results showed great variability in the relative numbers of bacteria producing other enzymes associated with genotoxicity, particularly with respect to GN and NR (Fig. 2). Although few data are available concerning the identities or physiologies of bacteria involved in NR formation in the large intestine, Rafii et al. [12] identified several clostridia that produced this enzyme, in a single human faecal sample, including $C$. leptum, $C$. paraputrificum and $C$. clostridiiforme. Their investigations confirmed that aromatic amines were the primary products of NR activity, and that the enzymes involved had broad substrate specificities. Other studies, with $C$. perfringens, demonstrated that $\mathrm{AR}$ and $\mathrm{NR}$ activities were manifested by a single enzyme [46]. Data in Table 4 which show that AR activities were comparable to NR ativities for $C$. perfringens provide further evidence for this. However, disparities in the MPN results shown in Fig. 2 indicate that this may not be a widespread trait in gut micro-organisms. Various colonic anaerobes have been reported to reduce a wide range of water soluble azo dyes that are used in foods, drugs and cosmetics, including fusobacteria, peptostreptococci, eubacteria, bacteroides, coprococci and acidaminococci [11]. This study also demonstrated that azo reduction was an anaerobic process that was inhibited by glucose in $B$. thetaiotaomicron. A physiological role for azo reduction, as an electron sink during anaerobic growth, has been suggested for Ent. faecalis [47]. The ability to dispose of excess reducing power in this way would be energetically favourable to fermentative bacteria growing in the large gut.

In this investigation, screening of a range of intestinal bacteria for their abilities to synthesise enzymes involved in the formation of genotoxins (Table 4) demonstrated that, in agreement with the MPN studies, GS and AR were the most commonly produced, while the taxonomic distribution of bacteria forming GN and AS was more restricted. In view of their ubiquity in the bowel, and their high levels of synthesis of GS, GN and NR (B. vulgatus), a key role can be postulated for Bacteroides spp. in intestinal genotoxicity. The expression of significant levels of GN and GS by several bifidobacterial species also implicates these organisms in the formation of toxic substances in the colon.

The physiological importance of AS activity in the large intestine is that sulphation of bile acids increases their polarity, thereby decreasing their enterohepatic circulation. Thus, desulphation of these genotoxic metabolities by colonic micro-organisms makes them more hydrophobic and reduces their faecal excretion. Very little is known concerning either the activities, numbers or taxonomies of AS-producing bacteria in the human large bowel. However, results obtained in this study indicate that $C$. perfringens together with some bacteroides and bifidobacteria form this enzyme, while an unspeciated clostridium has been isolated from rat faeces that produced an AS with restricted substrate specificities, which was active against $3 \alpha$-sulphate esters of bile salts but not $3 \beta$-, $7 \beta$ - or $12 \alpha$-sulphates [22]. Previous work had shown that AS formed by clostridia in the rat gut was oxygen sensitive [20].

One of the main reasons for bacterial species diversity in the large intestine is thought to be the wide range of substrates that are potentially available for fermentation [48]. In in-vitro experiments with the threestage gut model, faecal bacteria were grown on a wide range of polymerised carbon and nitrogen sources to maintain a complex ecosystem. The model was designed to reproduce the nutritional and physiochemical environments found in different regions of the colon. Thus, culture medium was fed to V1, which had the greatest nutrient availability and acid $\mathrm{pH}$ similar to the proximal colon; $\mathrm{pH}$ increased and cultures became progressively more nutrient-limited in vessels 2 and 3, as occurs in the distal bowel [49].

Transit time of digestive material through the large intestine is an important factor affecting growth and metabolism of colonic bacteria, particularly in the carbohydrate-limited distal bowel, and is typically $c$. $60-70 \mathrm{~h}$ in the United Kingdom [50]. Therefore, bacterial enzyme synthesis was studied at two system retention times in the colon model, one fast $(\mathrm{R}=$ $31.1 \mathrm{~h}$ ), the other similar to mean colonic transit times in the general population $(\mathrm{R}=68.4 \mathrm{~h})$.

Activities of enzymes such as GS, GN, AR, NR and 
AS in the colonic microbiota are influenced by various inducer and repressor substances acting in concert, and enzyme activators and deactivators may affect the metabolism of individual species in different ways. Data in Table 5 suggested that increases in cellassociated GS and GN in V2 and V3 at $R=31.1 \mathrm{~h}$ resulted from partial relief of catabolite regulation, in the presence of enzyme inducer, as carbon availability became limiting in these culture vessels. However, the reverse occurred with $\mathrm{NR}$, indicating depletion of enzyme inducers in V3 under C-limitation. At $\mathrm{R}=68.4 \mathrm{~h}$, GS activities declined from V1 to V3, demonstrating inducer-limitation under these culture conditions.

Cell-associated and extracellular GN and GS in the gut model could have been produced either by the same, or by different micro-organisms. The increase in extracellular activities of these enzymes observed from $\mathrm{V} 1$ to $\mathrm{V} 3$ at $\mathrm{R}=31.1 \mathrm{~h}$, and with $\mathrm{GS}$ at $\mathrm{R}=68.4 \mathrm{~h}$ may have been partly due to cell death and release of intracellular enzymes following lysis of bacteria, during culture under nutrient depletion. However, the absence of any extracellular GN at the higher retention time is indicative of limitation of enzyme inducer under these growth conditions.

Bacteriological measurements were made on the continuous culture system (Table 6), firstly to ascertain that a microbiota representative of the large intestine was maintained in the model, and secondly, to validate the enzyme data and determine whether variations in hydrolytic and reductive enzyme activities could be related to bacteriological changes that occurred during growth under different cultural conditions. With few exceptions, the marker bacterial populations varied little in different culture vessels (V1-V3); however, changing $\mathrm{R}$ from 31.1 to $68.4 \mathrm{~h}$ increased virtually all cell counts in the microbiota in all culture vessels.

Because specific activities of GS were up to four-fold higher (V3) at $\mathrm{R}=31.1 \mathrm{~h}$, the bacteriological analysis confirmed that changes in GS activity could not be related to numbers of the predominant anaerobic or aerobic species within the model, but that, similar to the feeding studies of Goldin and Gorbach [42], were explainable on the basis of substrate-induced modulation of bacterial metabolism.

\section{References}

1. Finegold SM, Sutter VL, Mathisen GE. Normal indigenous intestinal flora. In: Hentges DJ (ed) Human intestinal micro flora in health and diseae. London, Academic Press. 1983: 3.

2. Moore WEC, Holdeman LV. Human fecal flora: the normal flora of 20 Japanese-Hawaiians. Appl Microbiol 1974; 27: 961-979.

3. Gossling J, Slack JM. Predominant gram-positive bacteria in human feces: numbers, variety, and persistence. Infect Immun 1974; 9: 719-729.

4. Hill MJ. Metabolism of nitrogen compounds: miscellaneous compounds. In: Hill MJ (ed) Role of gut bacteria in human toxicology and pharmacology. London, Taylor and Francis. 1995: $79-92$

5. Macfarlane GT, Cummings $\mathrm{JH}$, Gibson GR. In vivo and in vitro studies on formation of phenols and phenolic acids by human colonic bacteria. Gastroenterology 1992; 102 Suppl A: 565 (Abstract)

6. Kinouchi T, Kataoka K, Miyanishi K, Akimoto S, Ohnishi Y. Biological activities of the intestinal microflora in mice treated with antibiotics or untreated and the effects of the microflora on absorption and metabolic activation of orally administered glutathione conjugates of K-region epoxides of 1-nitropyrene. Carcinogenesis 1993; 14: 869-874.

7. Weisburger JH. Chemical carcinogens: their metabolism and mode of action. Cancer 1971; 28: 60-70.

8. Weisburger JH. Chemical carcinogens and their mode of action in colonic neoplasia. Dis Colon Rectum 1973; 16: 431-437.

9. Sugimura T. Mutagens, carcinogens, and tumor promoters in our daily food. Cancer 1982; 49: 1970-1984.

10. Rafii F, Franklin W, Cerniglia CE. Azoreductase activity of anaerobic bacteria isolated from human intestinal microflora. Appl Environ Microbiol 1990; 56: 2146-2151.

11. Chung KT, Fulk GE, Egan M. Reduction of azo dyes by intestinal anaerobes. Appl Environ Microbiol 1978; 35: $558-562$.

12. Rafii F, Franklin W, Heflich RH, Cerniglia CE. Reduction of nitroaromatic compounds by anaerobic bacteria isolated from the human gastrointestinal tract. Appl Environ Microbiol 1991; 57: $926-968$

13. Manning BW, Campbell WL, Franklin W, Delclos B, Cerniglia CE. Metabolism of 6-nitrochrysene by intestinal microflora. Appl Environ Microbiol 1988; 54: 197-203.

14. Mallet AK, Bearne CA, Rowland IR, Farthing MJG, Cole CB, Fuller R. The use of rats associated with a human faecal flora as a model for studying the effects of diet on the human gut microflora. J Appl Bacteriol 1987; 63: 39-45.

15. Mallett AK, Bearne CA, Rowland IR. The influence of incubation $\mathrm{pH}$ on the activity of rat and human gut flora enzymes. $J$ Appl Bacteriol 1989; 66: 433-437.

16. Rowland IR, Mallett AK, Wise A. The effect of diet on the mammalian gut flora and its metabolic activities. Crit Rev Toxicol 1985; 16: 31-103.

17. Laqueur GL, Spatz M. The toxicology of cycasin. Cancer Res 1968; 28: 2262-2267.

18. Wilkins TD, Van Tassel LN. Production of intestinal mutagens In: Hentges DJ (ed) Human intestinal microflora in health and disease. London, Academic Press. 1983: 265.

19. Huijghebaert SM, Eyssen HJ. Isolation of (a) bile salt sulfataseproducing Clostridium strain from rat intestinal microflora. Appl Environ Microbiol 1982; 43: 185-192.

20. Huijghebaert SM, Eyssen HJ. Specificity of bile salt sulfatase activity from Clostridium sp. strain $\mathrm{S}_{1}$. Appl Environ Microbiol 1982; 44: 1030-1034.

21. Robben J, Caenepeel P, Van Eldere J, Eyssen H. Effects of intestinal microbial bile salt sulfatase activity on bile salt kinetics in gnotobiotic rats. Gastroenterology 1988; 94: 494-502.

22. Robben J, Parmentier G, Eyssen H. Isolation of a rat intestinal Clostridium strain producing $5 \alpha$ - and $5 \beta$-bile salt $3 \alpha$-sulfatase activity. Appl Environ Microbiol 1986; 51: 32-38.

23. McMichael AJ, Potter JD. Host factors in carcinogenesis: certain bile-acid metabolic profiles that selectively increase the risk of proximal colon cancer. J Natl Cancer Inst 1985; 75: 185-191.

24. Silverman SJ, Andrews AW. Bile acids: co-mutagenic activity in the Salmonella-mammalian-microsome mutagenicity test: brief communication. J Natl Cancer Inst 1977; 59: 1557-1559.

25. Chipman JK. Bile as a source of reactive metabolites. Toxicology 1982; 25: 99-111.

26. Tadaka $H$, Hirooka $T$, Hiramatsu $Y$, Yamamoto $M$. Effect of $\beta$ glucuronidase inhibitor on azoxymethane-induced colonic carcinogenesis in rats. Cancer Res 1982; 42: 331-334.

27. Cummings JH, Pomare EW, Branch WJ, Naylor CPE, Macfarlane GT. Short chain fatty acids in human large intestine, portal, hepatic and venous blood Gut 1987; 28: 1221-1227.

28. Wise A, Mallett AK, Rowland IR. Dietary protein and cecal microbial metabolism in the rat. Nutr Cancer 1983; 4: 267-272.

29. Alexander M. Most probable number method for microbial 
populations. In: Black CA (ed) Methods of soil analysis II. Madison, American Society of Agronomy. 1965: 1467-1472.

30. Holdeman LV, Cato EP, Moore WEC. Anaerobe laboratory manual, 4th edn. Blacksburg, Virginia Polytechnic Institute and State University. 1977.

31. Beerens $H$. An elective and selective isolation medium for Bifidobacterium spp. Lett Appl Bacteriol 1990; 11: 155-157.

32. Macfarlane GT, Gibson GR. Co-utilization of polymerized carbon sources by Bacteroides ovatus grown in a two-stage continuous culture system. Appl Environ Microbiol 1991; 57: $1-6$.

33. Macfarlane GT, Cummings JH, Allison C. Protein degradation by human intestinal bacteria. $J$ Gen Microbiol 1986; 132: $1647-1656$

34. Degnan BA, Macfarlane GT. Arabinogalactan utilization in continuous cultures of Bifidobacterium longum: effect of coculture with Bacteroides thetaiotaomicron. Anaerobe 1995; 1: $103-112$.

35. Morotomi M, Guillem JG, LoGerfo P, Weinstein IB. Production of diacylglycerol, an activator of protein kinase $C$, by human intestinal microflora. Cancer Res 1990; 50: 3595-3599.

36. Bruce WR, Dion PW. Studies relating to a fecal mutagen. $A m$ $J$ Clin Nutr 1980; 33 (11 Suppl): 2511-2512.

37. Dion P, Bruce WR. Mutagenicity of different fractions of extracts of human feces. Mutat Res 1983; 119: 151-160.

38. Ahnen DJ. Etiology of large bowel cancer. In: Phillips SF, Pemberton JH, Shorter RG (eds) The large intestine: physiology, pathophysiology and disease. New York, Raven Press. 1991: 501.

39. Van Tassell RL, Kingston DGI, Wilkins TD. Metabolism of dietary genotoxins by the human colonic microflora: the fecapentaenes and heterocyclic amines. Mutat Res 1990; 238: 209-221.

40. Rowland IR. Interactions of the gut microflora and the host in toxicology. Toxicol Pathol 1988; 16: 147-153.
41. Macfarlane GT, Gibson GR, Cummings JH. Extracellular and cell-associated glycosidase activities in different regions of the human large intestine. Lett Appl Microbiol 1991; 12: 3-7.

42. Goldin BR, Gorbach SL. The relationship between diet and rat fecal bacterial enzymes implicated in colon cancer. $J$ Natl Can Inst 1976; 57: 371-375.

43. Fujisawa $\mathrm{T}$, Mori $\mathrm{M}$. Influence of bile salts on $\beta$-glucuronidase activity of intestinal bacteria. Lett Appl Microbiol 1996; 22: 271-274.

44. Cummings JH, Wiggins HS, Jenkins DJA et al. Influence of diets high and low in animal fat on bowel habit, gastrointestinal transit time, fecal microflora, bile acid, and fat excretion. J Clin Invest 1978; 61: 953--963.

45. Reddy BS, Hanson D, Mangat S et al. Effect of high-fat, highbeef diet and mode of cooking of beef in the diet on fecal bacterial enzymes and fecal bile acids and neutral sterols. $J$ Nutr 1980; 110: 1880-1887.

46. Rafii F, Cerniglia CE. Comparison of the azoreductase and nitroreductase from Clostridium perfringens. Appl Environ Microbiol 1993; 59: 1731-1734.

47. Gingell R, Walker R. Mechanisms of azo reduction by Streptococcus faecalis. II. The role of soluble flavins. Xenobiotica 1971; 1: 231-239.

48. Macfarlane GT, Gibson GR. Metabolic activities of the normal colonic flora. In: Gibson SAW (ed) Human health: the contribution of microorganisms. London, Springer Verlag. 1994: $17-52$.

49. Macfarlane GT, Cummings $\mathrm{JH}$. The colonic flora, fermentation and large bowel digestive function. In: Phillips SF, Pemberton JH, Shorter RG (eds) The large intestine: physiology, pathophysiology and disease. New York, Raven Press. 1991: 51.

50. Cummings JH, Bingham SA, Heaton KW, Eastwood MA. Fecal weight, colon cancer risk, and dietary intake of nonstarch polysaccharides (dietary fiber). Gastroenterology 1992; 103: 1783-1789. 